\title{
IMPLEMENTASI E-EDITION MODERN STANDARD ARABIC (MSA) DALAM PEMBELAJARAN BAHASA ARAB
}

\author{
Ainun Syarifah \\ UIN Sunan Ampel Surabaya \\ Ainunsyarifah78@gmail.com
}

\begin{abstract}
Abstrack: The Language Development Center (P2B) is one of the institutions under management of UIN Sunan Ampel Surabaya. This program has responsibility in strengthening Arabic language competence for all students. The standardization of Arabic language competencies is an Arabic language learning intensification program that is managed by $\mathrm{P} 2 \mathrm{~B}$. P2B has made various efforts in improving student competence in Arabic, one of it is by reformulating the Arabic Language learning model, namely by implementing online learning using the E-edition Modern Standard Arabic (MSA) program. The Intensive Arabic Language learning program is done twice a week which are divided into two study groups based on the language competency classifications students. All Intensive Arabic Instructors have different learning strategies, adjusting the characteristics and competencies of their students in each class. As a final test is conducted using an online test called Final Online Test (FOT), It means to measure the results of the Arabic language learning that has been done. The type of this research is a qualitative descriptive analysis research, with deep interview, documentation, group discussion forum as data collection technique.
\end{abstract}

Kata Kunci: Modern standard Arabic (MSA), Arabic teaching, final Online Test

\begin{abstract}
Abstrak: Pusat Pengembangan Bahasa (P2B) adalah salah satu lembaga yang berada di bawah manajemen UIN Sunan Ampel Surabaya, program ini dihadapkan pada tanggung jawabnya dalam penguatan kompetensi bahasa Arab bagi seluruh mahasiswa. Standarisasi kompetensi bahasa Arab tersebut kemudian dituangkan dalam paket program intensifikasi pembelajaran bahasa Arab yang dikelola langsung oleh P2B. P2B telah melakukan berbagai upaya dalam meningkatkan kompetensi mahasiswa dalam Bahasa Arab, salah satu nya dengan mereformulasi Model pembelajaran Bahasa Arab itu sendiri, yaitu dengan mengimplementasikan pembelajaran secara online dengan menggunakan program E-edition Modern Standard Arabic (MSA). Program pembelajaran Intensif Bahasa Arab ini dilaksanakan selama dua pertemuan dalam seminggu yang terbagi dalam dua kelompok belajar yang disesuaikan dengan klasifikasi kompetensi bahasa yang dimiliki mahasiswa. Semua Instruktur Intensif bahasa Arab telah melakukan formulasi strategi pembelajaran yang berbeda-beda, dengan menyesuaikan karakteristik dan kompetensi mahasiswa mereka dimasing-masing kelas. Di akhir semester dua, untuk mengukur hasil pembelajaran Bahasa Arab yang telah dilaksanakan, maka dilaksanakan ujian akhir yang menggunakan test online yang disebut Final Onlinet Test (FOT). Program ini memiliki urgensi dan kualitas yang lebih baik karena dapat dioperasikan pada laptop, netbook, atau tablet PC. Jenis penelitian yang digunakan dalam penelitian ini adalah jenis penelitian analisis deskriptif kualitatif, dengan melakukan wawanara secara mendalam, dokumentasi, triangulasi dan FGD sebagai teknik pengumpulan data.
\end{abstract}

Kata Kunci: Modern Standard Arabic (MSA), pengajaran bahasa Arab, Tes online akhir.

\section{PENDAHULUAN}

Pembelajaran bahasa Arab di lembaga pendidikan, mulai dari tingkat dasar hingga perguruan tinggi, idealnya memungkinkan para peserta didik menguasai empat keterampilan berbahasa (maharat al-istima', maharat al-kalam, maharat al- 
qira'ah, dan maharat al-kitabah) secara fungsional dan proporsional' ${ }^{1}$. Untuk mencapai empat keterampilan itu, tentu saja bukanlah semudah membalik telapak tangan. Sebagaimana yang lazim diketahui, permasalahan yang dihadapi negaranegara non-Arab dalam pembelajaran bahasa Arab cukup banyak ${ }^{2}$, salah satunya adalah kurang tersedianya bahan ajar yang baik. Bahan ajar yang baik dibutuhkan dalam proses pembelajaran karena ia ikut menentukan berhasil-tidaknya mahasiswa dalam mencapai kompetensi kebahasaan yang dibutuhkannya.

Kalau kita mau menelisik secara historis perjalanan pengajaran bahasa Arab sebelumnya akan terlihat bahwa sebelum sistem pengajaran bahasa bersentuhan dengan metode pengajaran bahasa modern, maka bahasa Arab diajarkan dengan cara yang sangat sederhana dan bertumpu pada metode terjemah dengan mengandalkan buku-buku agama yang tertulis dalam bahasa Arab. Dengan begitu, waktu yang dibutuhkan untuk mengetahui bahasa Arab itu sangat lama dan panjang. Sistem penjenjangan pada waktu itu belum dikenal, bahkan pengajarannya masih bersifat khalaqah (non classical).

Setelah melalui beberapa fase dan abad, akhirnya pengajaran bahasa Arab memasuki era modern, yakni mulai bersentuhan dengan sistem pengajaran yang ada di Eropa, terutama setelah pemikir-pemikir Barat yang khusus melakukan kajian-kajian ketimuran mulai mencurahakan pemikirannya terhadap Islam, tentu saja dengan beragam motif mempelajarinya, maka usaha-usaha untuk mempermudah dalam mempelajari bahasa Arab dan mengajarkannya sebagai foreign language, mulai digalakkan.

Pusat Pengembangan Bahasa (P2B) adalah salah satu lembaga yang berada di bawah manajemen UIN Sunan Ampel Surabaya, program ini dihadapkan pada tanggung jawabnya dalam penguatan kompetensi bahasa Arab bagi seluruh mahasiswanya. Penguatan kompetensi bahasa Arab diposisikan sangat penting dalam rangka memahami, mendalami dan menguasai sumber ajaran Islam, yang kemudian diteruskan dan ditransformasikan kepada masyarakat. Di sisi lain

\footnotetext{
${ }^{1}$ Madkur, Ali A. Tadris Funun al-Lughah al-Arabiyyah (Kairo: Dar al-Fikr al-Araby, 2000) 5.

2 Abd al-Hamid al-Shalqani, al-Sijill al- 'Ilmiy li al-Nadwah al- 'Alamiyah al-Ula li Ta'lim al- 'Arabiyah li Ghayr al-Natiqin biha (Riyad: Mathabi" Jami" at al-Riyad, 1980), 24.
} 
penguatan kompetensi bahasa Arab tidak hanya respon terhadap realitas sosialreligius masyarakat, tetapi terkait juga dengan konteks komunikasi global.

Dalam rangka memenuhi tanggungjawab ini, UIN Sunan Ampel memformulasikan standarisasi kompetensi berbahasa Arab yang harus dimiliki oleh semua mahasiswa. Standarisasi kompetensi bahasa Arab tersebut kemudian dituangkan dalam paket program intensifikasi pembelajaran bahasa Arab yang dikelola langsung oleh P2B. Program ini dikhususkan bagi mahasiswa semester satu dan dua. Tujuannya adalah pada akhir semester dua diharapkan semua mahasiswa baru tersebut memiliki kemampuan bahasa Arab "standar" yang dapat dijadikan sebagai aset dan modal dalam perjalanan akademis-intelektualkomunikatif selanjutnya.

Program intensif bahasa Arab bagi mahasiswa baru ini sudah dilaksanakan sejak beberapa tahun terakhir, tepatnya sejak tahun 2000. Namun, dalam beberapa data menunjukkan bahwa program intensif yang diberlakukan bagi mahasiswa baru semester satu dan dua belum sepenuhnya menghasilkan output sesuai dengan yang diharapkan. Kemampuan standar yang diharapkan muncul masih belum dapat terealisasikan secara maksimal. Hal tersebut nampak sangat jelas ketika selesai program intensif pada semester dua, belum muncul peningkatan kemampuan yang signifikan dari para mahasiswa. Padahal, seharusnya kemampuan bahasa Arab "standar" yang meliputi kemampuan mendengar, berbicara, membaca dan menulis harus muncul sebagai hasil dari proses pembelajaran bahasa Arab yang dilakukan ${ }^{3}$.

P2B telah melakukan berbagai upaya dalam meningkatkan kompetensi mahasiswa dalam Bahasa Arab, salah satu nya dengan mereformulasi Model pembelajaran Bahasa Arab itu sendiri, yaitu dengan mengimplementasikan pembelajaran secara online dengan menggunakan program E-edition Modern Standard Arabic (MSA), dan baru diterapkan pada semester gasal tahun 2017 ini, yang awal mulanya Intensifikasi ini hanya menggunakan bahan ajar manual, yaitu berupa buku bahasa Arab yang telah ditentukan. E-edition Modern Standard Arabic (MSA) ini adalah hasil karya Prof. Dr. Eckehard Schulz, Universitas Leipzig

\footnotetext{
${ }^{3}$ Ali Ahmad Madzkur, Tadris Funun al-Lughah al-Arabiyyah (Riyadh: Dar al- Syawaf, 1991), 7.
} 
Jerman, program ini hadir sebagai respon atas tantangan praktis profesional maupun akademik dengan menggunakan media yang modern dan program ini memiliki urgensi dan kualitas yang lebih baik karena dapat dioperasikan pada laptop, netbook, atau tablet PC. Selama ini program ini telah diterapkan pada sebuah kursus dasar intensif bahasa arab untuk mahasiswa pemula di Institut Oriental Universitas Leipzig Jerman, dan ditujukan untuk belajar bahasa arab baku dan modern, baik dalam ragam tulisan maupun percakapan.

Berdasarkan fenomena ini, peneliti ingin mengetahui bagaimana implementasi E-edition Modern Standard Arabic (MSA) dalam pembelajaran Bahasa Arab di Fakultas Tarbiyah UIN Sunan Ampel Surabaya, apakah reformulasi ini dapat mengantarkan P2KBA pada tercapainya tujuan Intensifikasi Bahasa Arab, mampukah menghasilkan output sesuai dengan yang diharapkan. Kajian ini dilakukan dalam upaya untuk memahami kondisi yang terjadi sebenarnya sebagai bahan evaluasi untuk perbaikan program intensif Bahasa Arab selanjutnya dalam upaya mewujudkan kompetensi bahasa Arab yang standar bagi seluruh mahasiswa barunya.

\section{METODE PENELITIAN}

Jenis penelitian yang digunakan dalam penelitian ini adalah jenis penelitian deskriptif kualitatif. Untuk mendapatkan beberapa jenis data dari sumber data, maka dalam penelitian ini diperlukan adanya teknik pengumpulan data, antara lain: Observasi ${ }^{4}$, Wawancara (interview) secara mendalam, Dokumentasi ${ }^{5}$, Triangulasi ${ }^{6}$, dan FGD

Dalam triangulasi ditempuh langkah sebagai berikut: Membandingkan data hasil pengamatan dengan data hasil wawancara, membandingkan apa yang dikatakan orang di depan umum dengan apa yang dikatakan secara pribadi. Kemudian membandingkan hasil wawancara dengan isi suatu dokumen yang berkaitan.

\footnotetext{
${ }^{4}$ Sutrisno Hadi, Metodologi Research (Yogyakarta: Andi Offset, 1991), 136

${ }^{5}$ Arikunto, S. Prosedur Penelitian Suatu Pendekatan Praktis (Bandung :Rineka Cipta, 2002) 200

${ }^{6}$ J. Moleong, Metode Penelitian Kualitatif, (Bandung: Remaja Rosda Karya, 2007)300
} 
Adapun teknik analisis yang digunakan adalah model Analisis Interaktif. Di dalam model ini terdapat tiga komponen yang terdiri dari reduksi data, sajian data, dan penarikan kesimpulan atau verifikasi. Aktivitasnya berbentuk interaksi ketiga komponen analisis secara sistematik sebagai berikut:

Reduksi Data (Data Reduction) Reduksi data merupakan cara yang dilakukan peneliti dalam melakukan analisis untuk mempertegas, memperpendek, membuat fokus, membuang hal-hal yang tidak penting dan mengatur data sedemikian rupa sehingga dapat menarik kesimpulan atau memperoleh pokok temuan. Proses berlangsung hingga laporan akhir selesai atau dengan kata lain bahwa data adalah proses seleksi, penafsiran, penyederhanaan dan abstraksi data kasar. Dalam hal ini peneliti memilih dan menyeleksi datadata yang masuk yang berkaitan dengan implementasi E-edition Modern Standard Arabic dalam pembelajaran Bahasa Arab dan faktor pendukung dan penghambatnya, peneliti lebih menyederhanakan data-data tersebut, agar lebih focus pada obyek penelitian.

Sajian Data (Data Display) Supaya mendapat gambaran yang jelas tentang data keseluruhan, yang pada akhirnya akan dapat menyusun kesimpulan, maka peneliti berusaha menyusunnya ke dalam penyajian data dengan baik dan jelas agar dapat dimengerti dan dipahami. Pada sesi ini Peneliti menyajikan data dari hasil penelitian tentang implementasi E-edition Modern Standard Arabic dalam pembelajaran Bahasa Arab dan menyajikan tentang faktor pendukung dan penghambatnya dengan rinci dan jelas agar dapat dipahami alur dari obyek penelitian.

Penarikan Kesimpulan (Conclusion Drawing) Dalam penelitian ini seleksi data, penarikan kesimpulan sudah dimulai dari proses awal diperolehnya data. Kesimpulan dalam penelitian ini adalah merupakan temuan baru yang sebelumnya belum pernah ada. Temuan dapat berupa deskripsi atau gambaran suatu obyek yang sebelumnya masih remang-remang atau gelap sehingga setelah diteliti menjadi jelas, dapat berupa hubungan kausal atau interaktif, hipotesis atau teori. Setelag peneliti melakukan reduksi data dan data display, peneliti membuat kesimpulan tentang obyek penelitian yaitu implementasi E-edition Modern Standard Arabic dalam pembelajaran Bahasa Arab dan faktor pendukung 
dan penghambatnya. Dalam hal ini peneliti menyajikan temuan-temuan baru yang dapat memperjelas obyek penelitian, sehingga hasil penelitian menjadi lebih jelas dan lebih valid.

\section{HASIL PENELITIAN DAN PEMBAHASAN Intensif Bahasa Arab di UIN Sunan Ampel Surabaya}

Program intensif bahasa Arab pada dasarnya merupakan satu dari dua bagian program dari Pusat Pengembangan Bahasa (P2B) yang dikembangkan oleh UIN Sunan Ampel Surabaya disamping bahasa Inggris. Program ini merupakan model intensifikasi kegiatan belajar mengajar bahasa Arab dengan cara tatap muka antara instruktur dan mahasiswa di dalam atau diluar ruangan, yang menekankan pada aspek psikomotorik (ketrampilan), kognitif (pengetahuan) dan afektif (sikap) yang dilakukan secara terjadwal. Artinya, pembelajaran Intensif Bahasa Arab merupakan suatu kegiatan yang diberlakukan di seluruh jenjang Fakultas yang diatur secara langsung oleh Pusat Pengembangan Bahasa (P2B) yang bernaung di bawah Program Pengembangan Kompetensi Bahasa Asing P2KBA).

Artinya, pembelajaran Intensif Bahasa Arab merupakan suatu kegiatan yang diberlakukan di seluruh jenjang Fakultas yang diatur secara langsung oleh Pusat Pengembangan Bahasa (P2B) yang bernaung di bawah Program Pengembangan Kompetensi Bahasa Asing P2KBA).

Pada mulanya, program pembelajaran bahasa Arab di UIN Sunan Ampel Surabaya sepenuhnya dikelola oleh masing-masing Fakultas. Akan tetapi setelah diberlakukannya Keputusan Rektor UIN Sunan Ampel Surabaya tentang Pelimpahan Wewenang Penyelenggaraan Kompetensi Berbahasa Asing bagi Mahasiswa ke Pusat Pengembangan Bahasa (P2B) , maka aktivitas pembelajaran bahasa asing mulai tersentralkan. Regulasi apapun yang terkait dengan pengembangan kompetensi kebahasaan, baik berkaitan dengan rekrutmen tenaga instruktur, sampai penyeragaman buku ajar, semuanya tergantung ke P2B.

UIN Sunan Ampel Surabaya adalah Perguruan Tingi Islam yang mempunyai visi "Menjadi Universitas Islam yang unggul dan kompetitif bertaraf internasional". Maka sudah selayaknya kalau UIN Sunan Ampel Surabaya harus 
melaksanakan kajian - kajian keilmuan yang multidisipliner yang tercermin dalam kurikulumnya.

Dalam rangka memenuhi tuntutan tersebut, UIN Sunan Ampel Surabaya sejak tahun akademik 1999/2000 telah melaksanakan pembelajaran intensif bahasa Arab, dengan satu tesis bahwa bahasa Arab adalah merupakan kunci utama dalam memahami dan mempelajari kajian-kajian keilmuan tersebut yang mana hampir 80\% literatur yang dikaji oleh UIN Sunan Ampel Surabaya membutuhkan kemampuan atau penguasaan bahasa arab disamping bahasa Inggris sebagai bahasa asing kedua. Oleh karena itu sudah seharusnya kalau sistem pengajaran bahasa arab di UIN Sunan Ampel Surabaya harus terus ditingkatkan baik menyangkut alat - alat pengajaran, pendekatan, metode, materi, tenaga pngajar ataupun evaluasinya.

Institut Agama Islam negeri (UIN) Sunan Ampel Surabaya terletak di jalan Ahmad Yani, No. 117. Telp 0318410298 Surabaya. UIN Sunan Ampel Surabaya bersebelahan dengan Jatim Exspo di sebelah utaranya, sebelah baratnya ada Universitas Bhayangkara (UBHARA) dan kantor Kepolisian Daerah Jawa Timur. Sebelah selatan dan timurnyanya bersebelahan dengan perkampungan Wonocolo. Kampus ini letaknya sangat strategis, karena berada di depan jalan raya dan mudah dijangkau oleh lapisan masyarakat, baik pedesaan maupun kota.

Organisasi dalam suatu proses kegiatan belajar megajar merupakan salah satu faktor yang harus dimilki oleh setiap kelembagaan. Pengelola program Intensif Bahasa Arab ini berada di bawah naungan P2B UIN Sunan Ampel Surabaya, yang memiliki struktur kelembagaan yang terdiri dari penanggungjawab, ketua, Koordinator Bahasa Arab pusat, dan koordinator Bahasa Arab dimasing-masing fakultas :

Untuk tenaga pengajar, menurut data terakhir, instruktur bahasa Arab yang dimiliki UIN Sunan Ampel Surabaya hanya 83 orang dengan perincian Fakultas Adab Dan Humaniora berjumlah 9 orang, Fakultas Dakwah Dan Komunikasi 15 orang, Fakultas Syariah Dan Hukum 13 orang, Fakultas Ushuluddin Dan Filsafat 11 orang, Fakultas Ilmu Sosial Dan Ilmu Politik 13 orang, Fakultas Ekonomi Dan Bisnis Islam 5 orang, Fakultas Psikologi Dan Kesehatan 3 Orang, Sedangkan Fakultas Tarbiyah Dan Keguruan 16 orang. 


\section{Implementasi EEdition Modern Standard Arabic (MSA) dalam Pembelajaran}

\section{Bahasa Arab}

Implementasi E-Edition Modern Standard Arabic (Msa) Dalam pembelajaran bahasa Arab ini mencakup enam komponen, antara lain: target dan tujuan Pembelajaran intensif bahasa Arab, metode dan bentuk aktivitas pembelajaran intensif bahasa Arab, jadwal pembelajaran intensif bahasa Arab, desain materi dan bahan ajar pembelajaran intensif bahasa Arab, implementasi Eedition Modern Standard Arabic dalam pembelajaran intensif bahasa Arab di kelas, serta sistem evaluasi pembelajaran intensif bahasa Arab.

Sebagaimana target dan tujuan pembelajaran bahasa secara umum, pembelajaran intensif bahasa Arab di UIN Sunan Ampel Surabaya diselenggarakan dengan tujuan agar mahasiswa peserta program ini memiliki kemampuan dan keterampilan bahasa Arab secara aktif meliputi seluruh kompetensi kebahasaan, yaitu istima>' (pendengaran), kala>m (berbicara), qira>'ah (membaca), dan kita>bah (menulis) dengan baik dan benar dan sehingga mereka bisa mengikuti ujian akhir semester dengan baik dan lulus. Dengan demikian, maka segala bentuk aktivitas dan regulasi yang diberlakukan di dalamnya harus mengarah pada pencapaian tujuan tersebut.

Untuk mendukung ketercapaian grand goal yang telah direncanakan, maka pengelola pembelajaran Intensif bahasa Arab telah merancang metode, teknik, desaian dan bentuk aktivitas pembelajaran Intensif bahasa Arab diantaranya adalah: Hiwar Muwajjahah: dengan cara memberi topik tertentu dan unsur-unsur dari topik tersebut, Hiwar Hurrah: dengan cara memberi topik tertentu dan mahasiswa bebas menentukan topic sesuai dengan keinginan mereka sendiri, Penggunaan laboratorium bahasa: dengan sarana ini mahasiswa bisa belajar Bahasa Arab melalui E-edition Modern Standard Arabic dengan tujuan melatih keterampilan mereka terutama dalam berbicara dan mendengar, qirâ'ah Al-nuṣ̂̂s Al-'Arabiyah: dengan cara menelaah teks-teks bahasa arab dari buku manual yaitu kitab al-Arabiyah al-Muashirah, Tadrîb Al-kitâbah: memberikan latihan menulis dari tingkat sederhana (menyalin) imla' maupun insya' kitabi, Khitâbah: memberikan latihan berbicara bahasa arab di kelas. 
Program pembelajaran Intensif Bahasa Arab ini dilaksanakan selama 2 pertemuan pada tiap pagi mulai jam 06.00 sampai jam 07.40, yang terbagi dalam dua kelompok belajar dalam seminggu, yaitu kelompok A dan Kelompok B dengan mahasiswa yang berbeda. Pembagian kelas tersebut disesuaikan klasifikasi kompetensi bahasa yang dimiliki mahasiswa berdasarkan hasil placement test di awal perkuliahan. Bagi mahasiswa yang nilai placemet test nya tertinggi maka dia masuk pada kelas A. Sedangkan mahasiswa yang mendapatkan nilai terendah maka dia menempati kelas 0 kelas paling bawah. Pengklasifikasian ini bertujuan untuk memudahkan Instruktur dalam menyampaikan materi dan dalam menggunakan strategi pembelajaran, agar hasil pembelajaran dapat tercapai sesuai target.

Sebagaimana telah dipaparkan sebelumnya, terget dan tujuan pembelajaran Intensif Bahasa Arab adalah agar mahasiswa memiliki kompetensi berbahasa arab baik secara aktif maupun pasif yang diwujudkan dalam ketrampilan bahasa arab meliputi mendengar, berbicara, membaca dan menulis dengan baik dan benar. Dan indikator dari pencapaian kompetensi tersebut adalah mereka lulus dalam ujian Final Online Tes (FOT) yang mencakup tes mendengar, membaca dan menulis. Tes ini berbasis komputer dan internet yang bisa dilaksanakan kapan dan dimana saja, yang disebut dengan E-Toafl.

Buku al-Arabiyah al-Muashirah atau yang disebut dengan teks book offline terdiri dari beberapa unsur pembelajaran, antara lain: Terdiri dari 24 Pelajaran disertai latihannya untuk Level A1 - B2, Memuat tata bahasa berbasis praktik, Kosa kata berbasis analisis frekuensi, Mencakup pelajaran kemampuan membaca, memahami, berbicara dan menulis, Pengetahuan budaya dan sejarah, dll.

Dan E-edition book online ini memuat:Rekaman audio untuk tata bahasa, kosa kata dan teks, Percakapan dalam Bahasa Arab baku dan modern, Latihan interaktif berbasis computer, tablet dan smartphone, Memuat empat dialek Arab terpenting antara lain:Semenanjung Arab, Irak dan Teluk, Syria, Lebanon dan Palestina, Mesir, Libya dan Sudan, Maroko, Aljazair dan Tunisia.

Adapun salah satu syarat bagi para instruktur dan mahasiswa agar dapat mengakses E-edition Modern Standard Arabic adalah mereka harus memiliki email yang terdaftar dan teraktivasi. Karena kalau mereka tidak memiliki email 
yang terdaftar dan teraktivasi, maka mereka tidak bisa mengakses E-edition Modern Standard Arabic tersebut. Oleh karena itu P2KBA telah membuatkan email beralamatkan UINSA yang baru untuk semua dosen/instruktur dan mahasiswa serta sekaligus mendaftarkan dan mengaktivasikannya. Semua Instruktur Intensif bahasa Arab telah melakukan formulasi strategi pembelajaran yang berbeda-beda, dengan menyesuaikan karakteristik dan kompetensi mahasiswa mereka dimasing-masing kelas.

Di akhir pembelajaran yaitu pada akhir semester dua, untuk mengukur hasil pembelajaran Bahasa Arab yang telah dilaksanakan dalam dua semester, maka dilaksanakan ujian akhir yang menggunakan test online yang disebut Final Onlinet Test (FOT). Dan tes ini mencakup materi mendengar, membaca dan menulis yang mana bahan ujian diambil dari materi pembelajaran yang sudah diterapkan di kelas. Instruktur Bahasa Arab bisa mensetting sendiri FOT nya dan nanti hasil tes bisa diketahui secara langsung. Adapun hasil tes setara dengan A2 (pembelajaran 1 - 12). Tes online ini dapat diakses melalui https://etoafl.com/id/Test, sedangkan kemampuan bahasa Arab terdiri dari dua jenis standar (Common European Framework of Reference for Languages).Tes ini harus dilaksanakan di dalam laboratorium Bahasa, karena membutuhkan fasilitas yang lengkap untuk mengerjakan e-toafl ini. Dan pihak P2B telah memprogramkan tes online ini untuk masing-masing fakultas dan ditempatkan di laboratorium Bahasa UIN Sunan Ampel yang berada di Gedung Integrated Laboratorium. Dan dilaksanakan secara terjadwal, jadi mahasiswa dimasing-masing fakultas melaksanakan tes e-toafl secara bergiliran.

Dalam proses pembelajaran Bahasa Arab yang menggunakan E-edition Modern Standard Arabic, baik para Intrsuktur maupun mahasiswa pasti mendapati faktor yang mendukung dan yang menghambat mereka dalam melaksanakan proses tersebut. Setelah melakukan observasi dan wawancara secara mendalam, peneliti dapat mengkategorikan dari masing-masing faktor tersebut.

Adapun faktor pendukung dan penghambat dalam implementasi E-edition Modern Standard Arabic (MSA) adalah: Faktor Dosen/ Instruktur. Didalam implementasi E-edition Modern Standard Arabic, Instruktur atau tutor merupakan komponen yang sangat menentukan keberhasilan didalam pembelajaran intensif 
bahasa Arab di Fakultas Tarbiyah Dan Keguruan. P2b sangat selektif dalam merekrut dosen atau instruktur bahasa Arab di lingkungan UIN Sunan Ampel. P2B telah melaksanakan rekrutmen tersebut melalui seleksi yang ketat, yaitu dengan mengadakan tes berstandar Toafl yang nilai kelulusan minimal 500, kemudian bagi yang lulus tes Toafl harus mengikuti tes micro teaching. Dalam tes ini para calon harus melakukan praktek mengajar dan dinilai oleh para penilai yang kompeten dan kompatible. Disamping itu bagi calon instruktur yang lulus dari kedua tes tersebut, diharuskan mengikuti pelatihan dan workshop pembelajaran E-edition Modern Standard Arabic, agar mereka bisa mengetahui dan menguasai buku tersebut dan mampu menerapkan di dalam kelas

Demikian ini merupakan salah satu faktor penghambat dalam proses implementasi E-edition Modern Sandard Arabic di Fakultas Tarbiyah Dan keguruan, karena ketika dosen/intsruktur tidak mau menerapkan atau mengimplementasikan buku tersebut baik manual maupun online dalam kelas, maka mahasiswa tidak akan bisa menguasai materi buku tersebut dan akhirnya nanti mahasiswa tidak dapat mengikuti ujian akhir dengan baik.

Mahasiswa merupakan salah satu komponen yang dapat mendukung dan menghambat dalam penentuan berhasil atau tidaknya implementasi buku MSA tersebut. Mahasiswa juga merupakan faktor penting didalam keberhasilan implementasi buku MSA ini, namun berhubung latar belakang peserta didik yang heterogen, ada yang dari SMA, SMK dan ada yang dari MA/Pondok Pesantren, sehingga tidak semua mahasiswa mampu memahami materi bahasa Arab yang telah diajarkan, bahkan mereka tidak bersungguh-sungguh mengikuti pembelajaran.

Sarana dan prasarana merupakan faktor penting dalam suatu proses pengajaran, hal ini dikarenakan bahwa sarana dan prasarana yang baik tentu akan mendukung terciptanya kondisi pembelajaran yang baik pula.

Berdasarkan hasil observasi yang penulis laksanakan pada tanggal 10 September 2018, sarana dan prasarana di Fakultas Tarbiyah Dan Keguruan terutama digedung lama belum memadai, hal ini terlihat dari media pembelajaran yang belum disediakan yaitu wifi yang merupakan media yang paling penting dan 
sangat dibutuhkan mahasiswa dalam menerapkan dan mengimplementasikan pembelajaran berbasis online yang menggunakan E-edition Modern Standard Arabic , disamping itu laboratorium juga tidak disediakan untuk pembelajaran ini. Sehingga implementasi E-edition Modern Standard Arabic untuk pembelajaran bahasa Arab ini belum dapat dikatakan optimal. Namun sarana lain seperti, alatalat pembelajaran, sumber belajar (buku paket, kamus), LCD sudah dapat memadai. Akan tetapi pihak kampus masih proses melakukan penyempurnaan demi lancarnya kegiatan pembelajaran khususnya pembelajaran bahasa Arab berbasis online tersebut. Hasil survei dan wawancara dengan beberapa mahasiswa, peneliti mendapatkan informasi bahwa mayoritas mahasiswa masih belum memiliki laptop atau notebook, sehingga ketika mereka mencoba mengakses melalui handphone (HP) mereka sering mengalami kesulitan bahkan Ebook yang mereka akses sering trouble.

Dalam konteks pembelajaran intensif bahasa Arab di Fakultas Tarbiyah dan Keguruan, Program Pengembangan Kompetensi Bahasa Asing (P2KBA) sudah melakukan berbagai upaya dalam meningkatkan hasil pembelajaran yang dicapai agar mencapai tujuan dan target yang diinginkan, hal ini sebagaimana informasi yang didapat peneliti dari hasil wawancara secara mendalam dengan Ketua Pusat Pengembangan Bahasa (P2B) dan Koordinator Bidang Bahasa dalam Program Pengembangan Kompetensi Bahasa Asing (P2KBA). Terdapat beberapa kegiatan yang dilakukan P2B untuk menunjang keberhasilan pembelajaran para mahasiswa, diantaranya workshop untuk para instruktur yang dilaksanakan setiap tahun yang dihelat untuk mengevaluasi pembelajaran, sharing metode dan strategi yang diterapkan masing-masing instruktur di kelas, dan problem-problem yang dihadapi.

Untuk mencapai efektifitas pembelajaran di kelas, para instruktur dianjurkan menerapkan berbagai metode dan strategi, sesuai dengan topik pembelajaran dan sesuai dengan kemampuan mahasiswa. Demikian ini untuk menunjang keberhasilan mahasiswa pada saat Ujian akhir yang menggunakan ujian online atau yang disebut E-Toafl. Yang pertama peneliti memasuki kelas A, yang diampu oleh Bahauddin, M. Pd.I. Kelas A merupakan kelas yang paling unggul diantara kelas-kelas yang lain yang berada dibawahnya, karena pembagian kelas 
ini telah diklasifikasikan dari kelas A sampai 0 berdasarkan nilai hasil placement test.

Instruktur masuk kelas pada jam 06.05 pagi yang diawali dengan salam dan doa serta membaca surat pendek dalam alqur'an juz 30. Setelah itu seperti biasa instruktur mengabsen mahasiswa. Sebelum memulai materi pelajaran, instruktur mengintruksikan mahasiswa untuk membuka kitab sesuai halaman materi yang akan dipelajari. Kemudian instruktur menjelaskan strategi pembelajaran yang dipakai pada saat itu, yaitu strategi jigsaw.

Dalam setiap perkuliahan, Bahauddin selalu menggunakan thorîqoh mubâsyarah yaitu mengajarkan materi Bahasa Arab dengan menggunakan Bahasa Arab sebagai pengantarnya. Karena menurut dia, kompetensi Bahasa Arab mahasiswa di kelas A sangat menonjol, dan mereka bisa mengimbangi dan memahami penyampaian materi dengan menggunakan Bahasa Arab itu sendiri. Bahauddin juga seringkali menggunakan strategi jigsaw tersebut dalam pembelajarannya, karena strategi ini menurut dia lebih mengacu pada student center, demikian ini agar mahasiswa lebih aktif dalam belajar mandiri maupun kelompok, instruktur hanya sebagai fasilitator. Mahasiswa kelas A memang mahasiswa unggulan, hal ini terbukti dengan keaktifan mereka di kelas. Mereka dengan mudah memahami materi ketika berdiskusi dalam kelompok.

Berbeda dengan instruktur yang bernama Mazidatun Ahmala, M. Pd, kebetulan dia mengajar di kelas $\mathrm{N}$. kelas $\mathrm{N}$ merupakan kelas yang standar kompetensi mahasiswanya menengah kebawah. Dalam penerapan MSA ini baik yang buku manual maupun buku onlinenya, Mazidatun ahmala telah membuat formulasi strategi pembelajaran yang sekiranya membuat mahasiswa lebih aktif dan kreatif dalam belajar, dia telah menerapkan pendekatan student centre. Adapun langkah-langkah pembelajarannya antara lain:

Tepat pada jam 06.00 pagi Instruktur telah memasuki kelas dan mahasiswa telah siap di ruangan untuk menerima materi. Dalam pertemuan pertama kali, Instruktur hanya mengkondisikan kelas dengan melakukan perkenalan dan kontrak belajar, agar kelas lebih kondusif untuk kedepannya dan mahasiswa bisa belajar dengan tertib dan disiplin. Setelah itu sebelum perkuliahan diakhiri, 
Instruktur selalu memberikan tugas rumah (PR) kepada mahasiswa secara individu, tugas tersebut antara lain, masing-masing dari mereka diberi satu tema tiap pertemuan untuk dikerjakan, mereka boleh melihat jawaban yang telah tersedia di e-book tp tidak boleh monoton dg jawaban tersebut, mereka harus mencari referensi lain untuk menguatkan jawaban yang telah mereka dapatkan di e-book.

Kemudian pada pertemuan berikutnya, Instruktur membagi mereka dengan berpartner dua-dua untuk mengoreksi tugas mereka masing-masing, setiap partner saling berdiskusi sedangkan Instruktur hanya memantau perkembangan diskusi mereka, bagi mahasiswa yang kurang paham boleh menanyakan ke Instruktur dan akan dijelaskan oleh Instruktur. Setelah tugas mereka selesai, mereka diberi tugas untuk menghafalkan kosakata baru yang telah mereka dapatkan. Diakhir pembelajaran instruktur memberikan penguatan terkait materi yang telah dipelajari.

Strategi pembelajaran seperti ini selalu dilakukan oleh Mazidatun Ahmala pada tiap pertemuan, karena dia ingin mahasiswa lebih sering dan lebih aktif belajar melalui E-book nya, karena mahasiswa belum bisa mengakses E-edition Modern Standard Arabic di kelas, sebab belum ada fasilitas wifi yang bisa menyambungkan mereka pada internet.

Semua Instruktur Intensif bahasa Arab telah melakukan formulasi strategi pembelajaran yang berbeda-beda, dengan menyesuaikan karakteristik dan kompetensi mahasiswa mereka dimasing-masing kelas. Sebagaimana yang telah dilakukan oleh Indra Yumanto, S. Hum. Karena dia mengajar dikelas paling bawah yaitu kelas O. Dalam setiap proses pembelajaran dia lebih banyak menggunakan strategi tutorial dibandingkan pemberian tugas terstruktur kepada mahasiswa, karena kompetensi kebahasaan mereka sangat rendah dan bisa dikatakan kemampuan mereka nol dalam bahasa Arab, karena mayoritas mereka belum pernah belajar Bahasa Arab di sekolah sebelumnya.

Adapun langkah-langkah pembelajaran yang dilaksanakan oleh Indra Yumanto antara lain: Pada awal masuk Instruktur selalu mengucapkan salam dan selalu mengajak mahasiswa nya untuk berdoa sebelum belajar, agar mereka dapat 
menerima materi pelajaran dengan baik dan maksimal. Tidak lupa Instruktur mengabsen mereka satu persatu. Kemudian setelah itu Instruktur memulai pelajaran dengan menyuruh mereka membuka halaman dan bab yang akan dipelajari. Instruktur menjelaskan materi tersebut secara detail dan rinci sampai tuntas, kemudian untuk mengevaluasi hasil pembelajaran tersebut, untuk mengetahui sejauh mana penguasaan dan pemahaman mahasiswa terhadap materi yang telah dijelaskan tadi, instruktur memberikan tugas kepada mereka. Dan setelah itu tugas tersebut dikoreksi bersama-sama untuk diketahui kesalahan dan kebenarannya, dengan demikian mahasiswa juga dapat mengetahui nilai dari tugas yang dia kerjakan.

Untuk mencapai efektifitas pembelajaran di kelas, para instruktur dianjurkan menerapkan berbagai metode dan strategi, sesuai dengan topik pembelajaran dan sesuai dengan kemampuan mahasiswa. Demikian ini untuk menunjang keberhasilan mahasiswa pada saat Ujian akhir yang menggunakan ujian online atau yang disebut E-Toafl.

Setelah pemaparan data di atas, bagian analisis data ini hendak memaparkan beberapa temuan penting yang disarikan dari penelusuran melalui wawancara dan observasi partisipatif terhadap mahasiswa, Koordinator dan para instruktur program intensif bahasa Arab di Fakultas Tarbiyah dan Keguruan tahun akademik 2018-2019.

Dari beberapa wawancara yang dilakukan peneliti, dapat ditarik benang merah bahwa keberhasilan pembelajaran bahasa, termasuk di dalamnya bahasa Arab, tidak melulu ditanggungkan kepada kompetensi para pengajar, tapi sesungguhnya mencakup seluruh komponen yang meliputi kapasitas peserta didik, metode yang digunakan, media penunjang, dan kondisi lingkungan pembelajaran. Tentu saja, peran pengajar memang signifikan, tapi tidak dapat dipungkiri pula bahwa sistem yang dibangun, terutama oleh pemangku kebijakan, juga turut andil dalam suksesi pembelajaran bahasa.

Dalam konteks pembelajaran intensif bahasa Arab di Fakultas Tarbiyah dan Keguruan, Program Pengembangan Kompetensi Bahasa Asing (P2KBA) sudah melakukan berbagai upaya dalam meningkatkan hasil pembelajaran yang dicapai 
agar mencapai tujuan dan target yang diinginkan, hal ini sebagaimana informasi yang didapat peneliti dari hasil wawancara secara mendalam dengan Ketua Pusat Pengembangan Bahasa (P2B) dan Koordinator Bidang Bahasa dalam Program Pengembangan Kompetensi Bahasa Asing (P2KBA). Terdapat beberapa kegiatan yang dilakukan P2B untuk menunjang keberhasilan pembelajaran para mahasiswa, diantaranya workshop untuk para instruktur yang dilaksanakan setiap tahun yang dihelat untuk mengevaluasi pembelajaran, sharing metode dan strategi yang diterapkan masing-masing instruktur di kelas, dan problem-problem yang dihadapi.

Untuk mencapai efektifitas pembelajaran di kelas, para instruktur dianjurkan menerapkan berbagai metode dan strategi, sesuai dengan topik pembelajaran dan sesuai dengan kemampuan mahasiswa. Demikian ini untuk menunjang keberhasilan mahasiswa pada saat Ujian akhir yang menggunakan ujian online atau yang disebut E-Toafl.

Secara teoritis dan praktis, penggunaan metode eklektik memang lebih pas untuk kondisi mahasiswa yang beragam, terlebih pada program yang alokasi waktunya sangat minim. Dan itu sesungguhnya kelemahan mendasar yang dialami bukan hanya di fakultas Tarbiyah dan Keguruan, tapi juga di fakultas lain. Artinya, alokasi waktu yang sangat minim, ditambah beragamnya latar belakang dan kemampuan mahasiswa, menuntut para instruktur untuk senantiasa aktif dalam mencari terobosan-terobosan metode dan strategi yang pas untuk mereka, sebab belum ada lingkungan bahasa yang tercipta.

Dalam buku MSA ini terdapat petunjuk belajar secara tahap demi tahap agar dapat mengerti bahasa Arab baik lisan maupun tulisan, melatih kemampuan untuk berbicara, membaca, dan menulis teks dalam bahasa Arab. Jadi Bahasa harus diajarkan melalui pendekatan keterampilan, keterampilannya ada empat: mendengar, berbicara, membaca dan menulis. Tetapi keterampian berbicara ini harus dominan dan mengatasi semuanya. Harus meliputi semua kegiatan pembelajaran dalam kelas. Artinya, sekalipun keterampilan itu membaca, tetapi nanti di-lilit dengan berbicara. Topik bahasannya berupa keterampilan menulis, misalnya, maka sebelumnya harus idiskusikan dulu teksnya yang akan ditulis. Berbicara pun begitu. Mereka mendengarkan telling story lebih dulu, cerita 
pendek, kemudian cerita itu yang didiskusikan. Dan dosen harus banyak diam, hanya sekedar memberikan stimulus, yang kemudian harus dilakukan oleh peserta. Peserta itulah yang harus melakukan kegiatan berbahasa, baik mendengar, berbicara, membaca dan menulis. Bukan instrukturnya. Instruktur hanya sebagai fasilitator.

Pembelajaran Bahasa arab intensif ini telah menggunakan dua bentuk bahan ajar, yaitu bahan ajar cetak dan bahan ajar berbasis multimedia. Hal ini Sebagaimana yang telah diungkapkan oleh Mulyasa bahwa bentuk bahan ajar atau materi pembelajaran antara lain adalah bahan cetak (handout, buku, modul, LKS, brosur, dan leaflet), audio (radio, kaset, cd audio), visual (foto atau gambar), audio visual (seperti; video/ film atau VCD) dan multi media (seperti; CD interaktif, computer based, dan internet. Oleh karena itu pembelajaran berbasis internet ini otomatis membutuhkan media penunjang yaitu wifi yang dapat menyambungkan mahasiswa ke internet tersebut.

MSA ini merupakan pembelajaran Bahasa Arab yang menggunakan pendekatan berbasis media. Di samping pendekatan ini memiliki peranan yang sangat vital di dalam mengkomunikasikan pengalaman peserta didik, Di sisi lain, pendekatan berbasis media ini memiliki tujuan untuk memperjelas konteks makna kata, kalimat dan konsep-konsep baru kultural melalui penggunaan foto, peta, gambar, sampel hidup, kartu dan lain sebagainya terkait dengan aspek yang dapat membantu pemahaman peserta didik terhadap simbol-simbol kata asing. Pengembangan media ini dilengkapi dengan kaset, video, $C D$, Slide serta computer. Sehingga untuk mendukung implementasi E-edition Modern Standard Arabic dalam pembelajaran Bahasa Arab ini, agar dapat mencapai tujuan yang diharapkan, diperlukan usaha yang maksimal dari para pemangku jabatan dalam pemenuhan kebutuhan terkait pembelajaran ini, antara lain sarana prasarana pembelajaran yang dibutuhkan. Karena implementasi E-edition Modern Standard Arabic ini sangat bergantung dengan adanya media penunjang seperti wifi dan laboratotorium bahasa. Karena tanpa kedua media dan sarana tersebut, baik instruktur maupun mahasiswa tidak mungkin bisa mengimplementasikan pembelajaran yang berbasis online dan multimedia tersebut dengan maksimal. 
Walaupun sebenarnya ada buku manualnya, namun sebenarnya materi dalam buku manual tersebut ada keterkaitan dengan e-book nya/buku onlinenya.

Sebenarnya laboratarium bahasa sudah lama tersedia di kampus UIN sunan Ampel, namun sampai saat ini program Intensif bahasa Arab ini belum dijadwalkan untuk menggunakan laboratorium itu. Sehingga pembelajaran Bahasa Arab berbasis online ini menuntut mahasiswa untuk memiliki sarana prasarana sendiri seperti laptop untuk menunjang pembelajaran tersebut, sedangkan kenyataannya tidak semua mahasiswa memilikinya. Dan karena di Gedung perkuliahan tempat mereka belajar belum tersedia wifi aktif, maka instruktur maupun mahasiswa tidak bisa mengakses E-edition Modern Standard Arabic ketika belajar di kelas, akhirnya dalam setiap proses pembelajaran, mereka hanya masih berkutat menggunakan kitab Manualnya, yaitu kitab al-Arabiyah alMuashirah dan ini mengakibatkan pembelajaran berjalan dengan kurang efektif. Karena seharusnya mereka harus sering berlatih dan belajar tentang materi dan latihan-latihan yang terdapat di e-book nya atau E-edition Modern Standarad Arabics sebagai bekal mereka dalam mengikuti ujian akhir semester nanti yang berupa e-tes atau e-toafl.

Pada akhirnya para instruktur menuntut mahasiswa untuk sering berlatih sendiri di luar kelas, demikian ini sebenarnya juga kurang efektif, karena mereka tidak dibimbing langsung oleh dosen/instrukturnya, jadi tidak dapat dikontrol langsung oleh instruktur apakah mereka dapat mempelajari materi e-booknya dengan baik, apakah mereka mampu mengerjakan latihan-latihan yang di e-book, apalagi notabene asal sekolah mereka berbeda-beda, malah tidak sedikit mahasiswa yang belum pernah belajar Bahasa Arab sama sekali.

Inilah tugas besar yang harus dipikirkan jalan keluarnya terutama oleh para pemangku jabatan di UIN Sunan Ampel Surabaya. Upaya peningkatan pembelajaran Bahasa Arab dengan menggunakan E-edition Modern Standard Arabic ini harus ditunjang dengan pemenuhan terhadap fasilitas dan sarana prasarana yang dibutuhkan.

\section{KESIMPULAN}


Berdasarkan hasil penelitian yang dilakukan dengan mengacu pada rumusan masalah yang sudah ditetapkan, peneliti dapat menyimpulkan bahwa Implementasi E-edition Modern Standard Arabic dalam pembelajaran Bahasa Arab di fakultas Tarbiyah UIN Sunan Ampel Surabaya merupakan reformulasi yang telah dilakukan oleh program pengembangan Bahasa Asing (P2KBA) terhadap pembelajaran bahasa Arab di program Bahasa Arab Intensif, yang bertujuan untuk meningkatkan kualitas kompetensi bahasa Arab mahasiswa UIN Sunan Ampel Surabaya. Dalam implementasi E-edition Modern Standard Arabic ini mencakup enam komponen yang secara fokus dijelaskan dalam penelitian ini, antara lain: target dan tujuan Pembelajaran intensif bahasa Arab, metode dan bentuk aktivitas pembelajaran intensif bahasa Arab, jadwal pembelajaran intensif bahasa Arab, desain materi dan bahan ajar pembelajaran intensif bahasa Arab, implementasi Eedition Modern Standard Arabic dalam pembelajaran intensif bahasa Arab di kelas, serta sistem evaluasi pembelajaran intensif bahasa Arab.

Sebagaimana target dan tujuan pembelajaran bahasa secara umum, pembelajaran intensif bahasa Arab di UIN Sunan Ampel Surabaya diselenggarakan dengan tujuan agar mahasiswa peserta program ini memiliki kemampuan dan keterampilan bahasa Arab secara aktif meliputi seluruh kompetensi kebahasaan, yaitu istimâ' (pendengaran), kalâm (berbicara), qirâ'ah (membaca), dan kitâbah (menulis) dengan baik dan benar dan sehingga mereka bisa mengikuti ujian akhir semester dengan baik dan lulus.

Oleh karena itu P2B mencoba mereformulasi pembelajaran Intensif bahasa Arab ini dengan menggunakan E-edition Modern Standar Arabic (MSA), yang mulai diimplementasikan pada tahun 2017. Dalam hal ini UIN Sunan Ampel telah melakukan kerjasama dengan The Institute of Oriental Studies (IOS), Leipzig University, Jerman yang dikemas dalam program Center of Excellence in Teaching and Testing of Arabic (CETTA).

Untuk mendukung ketercapaian grand goal yang telah direncanakan, maka pengelola pembelajaran Intensif bahasa Arab telah merancang metode, teknik, desaian dan bentuk aktivitas pembelajaran Intensif bahasa Arab antara lain, hiwar muwajjahah, hiwar hurroh, Penggunaan laboratorium Bahasa, Qirâah al-Nuṣûsh Al-Arabiyah, Tadrîb al-Kitâbah dan Muhadatsah. 
Program pembelajaran Intensif Bahasa Arab ini dilaksanakan selama 2 pertemuan dalam seminggu yang terbagi dalam dua kelompok belajar, yaitu kelompok A dan Kelompok B dengan mahasiswa yang berbeda. Pembagian kelas tersebut disesuaikan klasifikasi kompetensi bahasa yang dimiliki mahasiswa berdasarkan hasil placement test di awal perkuliahan. Semua Instruktur Intensif bahasa Arab telah melakukan formulasi strategi pembelajaran yang berbeda-beda, dengan menyesuaikan karakteristik dan kompetensi mahasiswa mereka dimasingmasing kelas. Di akhir pembelajaran yaitu pada akhir semester dua, untuk mengukur hasil pembelajaran Bahasa Arab yang telah dilaksanakan dalam dua semester, maka dilaksanakan ujian akhir yang menggunakan test online yang disebut Final Onlinet Test (FOT).

Dalam proses pembelajaran Bahasa Arab yang menggunakan E-edition Modern Standard Arabic, baik para Intrsuktur maupun mahasiswa pasti mendapati faktor yang mendukung dan yang menghambat mereka dalam melaksanakan proses tersebut. Berdasarkan hasil penelitian faktor pendukung dan penghambat dalam implementasi E-edition Modern Standard Arabic ini disimpulkan dalam tiga kategori, yaitu Faktor Dosen/ Instruktur, Faktor Mahasiswa dan Faktor Sarana dan Prasarana.

Instruktur bahasa Arab merupakan faktor penting yang mendukung dalam implementasi/penerapan E-edition Modern Standard Arabic dalam pembelajaran bahasa Arab di Fakultas Tarbiyah Dan Keguruan UIN Sunan Ampel Surabaya. Karena mereka merupakan para dosen/instruktur terpilih dan berkompeten dalam Bahasa Arab serta profesional dalam pengajarannya. Mahasiswa juga merupakan faktor penting didalam keberhasilan implementasi buku MSA ini, namun berhubung latar belakang peserta didik yang heterogen, ada yang dari SMA, SMK dan ada yang dari MA/Pondok Pesantren, sehingga tidak semua mahasiswa mampu memahami materi bahasa Arab yang telah diajarkan, bahkan mereka tidak bersungguh-sungguh mengikuti pembelajaran.

Sarana dan prasarana di Fakultas Tarbiyah Dan Keguruan terutama digedung lama belum memadai, hal ini terlihat dari media pembelajaran yang belum disediakan yaitu wifi yang merupakan media yang paling penting dan sangat dibutuhkan mahasiswa dalam menerapkan dan mengimplementasikan 
pembelajaran berbasis online yang menggunakan E-edition Modern Standard Arabic, disamping itu laboratorium juga tidak disediakan untuk pembelajaran ini. Sehingga implementasi E-edition Modern Standard Arabic untuk pembelajaran bahasa Arab ini belum dapat dikatakan optimal. Namun sarana lain seperti, alatalat pembelajaran, sumber belajar (buku paket, kamus), LCD sudah dapat memadai. Akan tetapi pihak kampus masih proses melakukan penyempurnaan demi lancarnya kegiatan pembelajaran khususnya pembelajaran bahasa Arab berbasis online tersebut.

\section{DAFTAR PUSTAKA}

Taufik, "Pembelajaran Bahasa Arab MI”. Surabaya : UIN Sunan Ampel Press, 2016.

Madkur, Ali A. "Tadris Funun al-Lughah al-Arabiyyah", Kairo: Dar al-Fikr al-Araby, 2000.

al-Shalqani, Abd al-Hamid. "al-Sijill al-'Ilmiy li al-Nadwah al-'Alamiyah al-Ula li Ta'lim al-'Arabiyah li Ghayr al-Natiqin biha”. Riyad: Mathabi" Jami" at al-Riyad, 1980.

Madzkur, Ali Ahmad. “Tadris Funun al-Lughah al-Arabiyyah”. Riyadh: Dar al- Syawaf, 1991.

Mustofa, Syaiful, “Strategi Pembelajaran Bahasa Arab Inovatif”, Malang: UIN Malang Press, 2011.

Hadi, Sutrisno, Metodologi Research . Yogyakarta: Andi Offset, 1991

Arikunto, S. Prosedur Penelitian Suatu Pendekatan Praktis. Bandung :Rineka Cipta, 2002

J. Moleong, Metode Penelitian Kualitatif. Bandung: Remaja Rosda Karya, 2007

Abd al-Hamid al-Shalqani, al-Sijill al-'Ilmiy li al-Nadwah al-'Alamiyah al-Ula li Ta'lim al-'Arabiyah li Ghayr al-Natiqin biha. Riyad: Mathabi" Jami" at al-Riyad, 1980 